\title{
PRODUCTION AND PHYSICOCHEMICAL CHARACTERIZATION OF XANTHAN GUM BY NATIVE LACTOSE CONSUMING ISOLATES OF Xanthomonas citri subsp. citri
}

\author{
R. MORAVEJ ${ }^{1}$, S. M. ALAVI ${ }^{2 \bowtie}$, M. AZIN ${ }^{3}$, A. H. SALMANIAN ${ }^{2}$ \\ ${ }^{1}$ Department of Biology, Science and Research Branch, Islamic Azad University, Tehran, Iran; \\ ${ }^{2}$ Department of Plant Biotechnology, National Institute of Genetic \\ Engineering and Biotechnology (NIGEB), Tehran, Iran; \\ ${ }^{3}$ Department of Biotechnology, Iranian Research Organization for Science \\ and Technology (IROST), Tehran, Iran;

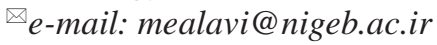

Received: 30 September 2019; Accepted: 29 November 2019

Xanthan is a biopolymer produced by Xanthomonas bacteria which is widely used in many industries such as food and oil. In this work, three Xanthomonas strains (X. citri/NIGEB-88, X. citri/NIGEB-386 and $X$. citri/NIGEB-K37) were used to evaluate their industrial potential to produce xanthan gum in whey medium. Bacteria growth rate, viscosity, biomass, dry weigh of produced xanthan and $\beta$-galactosidase activity were studied during the fermentation process and the presence of $\beta$-galactosidase genes was assessed by PCR technique. Strain NIGEB-386 had the best ability to utilize lactose in the whey medium. The highest amount of xanthan production and viscosity were $22.7 \mathrm{~g} / \mathrm{l}$ and $2066.6 \mathrm{mPa} \cdot \mathrm{s}$, respectively. The presence of six $\beta$-galactosidase genes in strains NIGEB-386 and NIGEB-K37 was confirmed. The pyruvate and acetyl contents in xanthan gum were 2.1 and $0.29 \%$, respectively. Fourier-transform infrared spectroscopy analysis determined the position of the functional groups in the structure of the fermentation product. In whey medium, the performance of both NIGEB-386 and NIGEB-K37 strains were better than the X. campestris. The findings showed that Xanthomonas citri/NIGEB-386 is suitable for industrial production of xanthan using cheese whey as a low-cost medium.

Keywords: Xanthomonas citri, Xanthan gum, cheese whey, $\beta$-galactosidase, pyruvate and acetate content, FTIR.

$\mathrm{T}$ he genus of Xanthomonas comprises different species that cause multiple diseases in a wide variety of plant species. Bacterial citrus canker is one of the most destructive citrus diseases caused by Xanthomonas citri subsp. citri (Xci) [1]. This bacterium is able to produce water-soluble exopolysaccharides that can sustain bacteria in poorly maintained environments. This polymer, which is also called xanthan, plays a role in biofilm formation and bacterial pathogenicity [2]. Xanthan has unique properties such as high viscosity, pseudo elasticity and stability at various temperatures, and because of the later, it is widely used in many fields of food, oil and pharmaceutical industries [3]. Xanthan gum is an emulsifier that helps ingredients to blend more effectively. It is also used as a thickener in many fatfree foods. In pastry fillings, it prevents water from seeping out and soaking the dough [4]. The structure of xanthan gum consists of cellulose like skeleton with different proportions of mannose, glucose, glucuronic acid, pyruvic acid and acetyl groups attached to the side chain, and thus creating different rheological properties in xanthan solutions [5]. Based on the substitution of the acetyl and pyruvic acid units in the side chain of the xanthan structure, its molecular weight varies. Generally, $66-88 \%$ and $5-21 \%$ of mannose in the side chain of xanthan undergo pyruvation and acetylation, respectively [6]. There are a lot of reports on the use of Xanthomonas campestris as a major strain in xanthan production; however, there

(C) 2020 Moravej R. et al. This is an open-access article distributed under the terms of the Creative Commons Attribution License, which permits unrestricted use, distribution, and reproduction in any medium, provided the original author and source are credited. 
are limited ones on using Xanthomonas citri species as producer of xanthan gum. The synthesis of xanthan gum is believed to be similar to exopolysaccharide synthesis by other gram negative bacteria. Xanthan is produced through aerobic fermentation at a temperature between $27{ }^{\circ} \mathrm{C}$ and $30^{\circ} \mathrm{C}$ [22]. In industrial scale, the xanthan gum is normally produced by batch fermentation, thermal treatment, cell removal, recovery with alcohol, drying and milling of the gum [3]. Generally, xanthan is produced from carbon sources such as glucose, sucrose and starch [7]. Sugar concentration in the range of $2-4 \%$, in the culture media, has been reported to be optimal for xanthan production [3]. In the commercial process, the microorganism can convert approx. $70 \%$ of substrate to gum [22]. However, due to the relatively high costs of these sugars, the production of xanthan gum is costly $[8,9]$. In this case, the use of dairy wastes such as a carbon substrate can be considered as a proposed solution for xanthan production because not only it decreases environmental pollution, but also it reduces the production cost.

Whey contains approximately 4-5\% (w/v) lactose, $8-10 \%(\mathrm{w} / \mathrm{v})$ proteins, as well as small amounts of organic acids, minerals and vitamins [10]. Hence, whey is considered as a highly valuable growth medium for microbial process and it could be chosen as a cheap substrate for xanthan production. Most of Xanthomonas wild species do not consume lactose because of their low $\beta$-galactosidase activity. To solve this problem, several efforts have been made to transfer the $\beta$-galactosidase genes by plasmid or phage vectors to Xanthomonas genome and forcing the bacteria into the lactose consumption [11]. The use of mutagenesis methods with mutagenic agents such as Nitric acid, Ethyl Methane sulfonate (EMS), Acridine dye and UV radiation has also been used to develop mutated strains for lactose consumption $[12,13]$. But genetic modification is usually associated with some disadvantages, including the production of antibiotic-resistant strains and strain instability [12]. The risk of genetically modified organisms (GMO) in food industries may also be a prohibitive factor. To solve this problem, the best option is to use the native strains of Xanthomonads that naturally have the ability to use lactose for xanthan production [14].

According to the recent studies, several new strains of Xanthomonas citri have been isolated from citrus plants in the southern part of Iran [15]. Based on these reports, we selected three native
Xanthomonas citri subsp. citri strains, NIGEB-K37, NIGEB-088 and NIGEB-386, and compared their respective capabilities to produce xanthan in cheesewhey medium. Moreover, we looked for the presence of $\beta$-galactosidase genes in these strains, which could play an important role in lactose consumption for xanthan production.

\section{Materials and Methods}

Microorganism and media. Three local isolates of Xanthomonas citri subsp. citri, NIGEBK37, NIGEB-088 and NIGEB-386, were obtained from NIGEB's Bacterial Citrus Canker Collection. X. campestris pv. campestris DSMZ1706 (XcC) DSMZ1706) was used as a control. Yeast malt (YM) agar containing $3 \mathrm{~g} \cdot \mathrm{l}^{-1}$ yeast extract, $3 \mathrm{~g} \cdot \mathrm{l}^{-1}$ malt extract, $5 \mathrm{~g} \cdot \mathrm{l}^{-1}$ peptone, $10 \mathrm{~g} \cdot \mathrm{l}^{-1}$ glucose, $20 \mathrm{~g} \cdot \mathrm{l}^{-1}$ agar in distilled water ( $\mathrm{pH}$ 7.2) was used as a culture medium for $X_{c i}$ strains. These bacterial strains were maintained at $30 \pm 1{ }^{\circ} \mathrm{C}$ on YM agar slants and subcultured every 15 days for six months to prevent the strains from losing their production capability [3].

Preparation of inoculum. For pre-culture preparation, cells were initially inoculated into the YM agar and incubated at $28{ }^{\circ} \mathrm{C}$ for $18-24$ hours until colonies were developed on the surface of the medium. Cell propagation was done in two steps. As the first step, one loopful of the cells was transferred into $50 \mathrm{ml}$ of $\mathrm{YM}$ broth medium and incubated at $28{ }^{\circ} \mathrm{C}, 120 \mathrm{rpm}$, till an optical density of 2 (at $600 \mathrm{~nm}$ ) was reached. Two $\mathrm{ml}$ of this pre-inoculum was then transferred to a $500 \mathrm{ml}$ flask, containing $100 \mathrm{ml}$ of the YM broth, and incubated at $28{ }^{\circ} \mathrm{C}$, $120 \mathrm{rpm}$ for $24 \mathrm{~h}$. Before inoculation of preculture to the production medium, cell concentration reached to about $1 \times 10^{8}$ colony forming units (CFU) $\mathrm{ml}^{-1}$ [9].

Cheese-Whey Preparation and Xanthan Production. The production medium, which was used for xanthan production, was prepared based on cheese whey powder (Pegah Dairy Co. Tehran, Iran) as a carbon source. Ingredients of the whey powder are shown in Table 1 . Cheese proteins were precipitated and removed by heat treatment. $60 \mathrm{~g}$ of whey powder was dissolved in 1 liter of distilled water and heated for $10 \mathrm{~min}$ at $100{ }^{\circ} \mathrm{C}$. After heating, the medium was filtered and the supernatant was centrifuged at $10,000 \times \mathrm{g}$ for $10 \mathrm{~min}$ for removing the precipitate [9]. The production medium was prepared by the addition of the following compounds to 1 liter of treated whey: $2.1 \mathrm{~g}$ Citric acid, $3 \mathrm{~g} \mathrm{KH}_{2} \mathrm{PO}_{4}, 0.3 \mathrm{~g}$ $\mathrm{MgSO}_{4}, 0.04 \mathrm{~g} \mathrm{CaCO}_{3}, 0.014 \mathrm{~g} \mathrm{H}_{3} \mathrm{BO}_{3}, 0.02 \mathrm{~g} \mathrm{ZnSO}_{4}$, 
Table 1. Composition of cheese whey powder

\begin{tabular}{l|c}
\hline \multicolumn{1}{c|}{ Contents } & Values (\%) \\
\hline Fat & 1 \\
Protein & 14.5 \\
Lactose & 67 \\
Ash & 8.2 \\
Minerals & 8 \\
\hline
\end{tabular}

$0.008 \mathrm{~g} \mathrm{FeCl}_{3} 6 \mathrm{H}_{2} \mathrm{O}$, and $2.2 \mathrm{~g}$ spray-dried corn steep liquor. Liquid Corn steep liquor (6\% dry solids) was procured from Glucosan Co. Ghazvin, Iran, and sprays dried by an APV Compact ${ }^{\circledR}$ Spray Dryer (APV Anhydro AS, Denmark). The $\mathrm{pH}$ of the medium was adjusted to 7.15 by adding $\mathrm{NaOH}$ before autoclaving [3]. $100 \mathrm{ml}$ of the production medium was inoculated with $10 \%(\mathrm{v} / \mathrm{v})$ of inoculum from the previous stage and incubated at $28{ }^{\circ} \mathrm{C}$ on a rotary shaker at $200 \mathrm{rpm}$ for 5 days. During the fermentation process, sampling was carried out at 24-hour intervals, and $\beta$-galactosidase activity, residual sugar, viscosity, and xanthan content were measured [16].

Measurement of Bacterial Growth. Bacterial growth was measured spectrophotometrically in $600 \mathrm{~nm}$ (UV Spectrophotometer-Unicam 8620). Enumeration of live cells was also done by the plate count method on YM agar [16].

Determination of Lactose Utilization and $\beta$-Galactosidase Activity. In order to evaluate and compare lactose consumption and $\beta$-galactosidase activity of strains during fermentation, sampling was carried out at intervals of 0 to $120 \mathrm{~h}$ and each sample was treated with acid hydrolysis method [17]. Then, the amount of sugar was measured by DNS method [18]. The assay of the enzyme activity was performed as described by Miller [18]. One unit of $\beta$-galactosidase was defined as the amount of enzyme that produced $1 \mathrm{nmol}$ of ortho-nitrophenol (ONP) per min [10, 18].

Measurement of Viscosity and Dry Weight of Xanthan. Analysis of apparent viscosity was carried out to assess the rheological feature of the produced xanthan [16]. The viscosity of the fermentation broth was measured by using BROOK-FIELD DV-II viscometer at $25{ }^{\circ} \mathrm{C}[15,19]$. To obtain the amount of xanthan produced, the samples were taken at specific time intervals, diluted with distilled water $(1: 1 \mathrm{v} / \mathrm{v})$, and centrifuged at $10000 \times \mathrm{g}$ for $15 \mathrm{~min}$ at $4{ }^{\circ} \mathrm{C}$ for separating the cells. The supernatant was mixed with ethanol $(1: 3 \mathrm{v} / \mathrm{v})$ [3] to precipitate the polymer. The biopolymer was separated and dried by freeze-drying (LYOVACTM-GT 3) and weighed $[3,16]$.

Detection of $\beta$-Galactosidase Genes by $P C R$. The Multiplex-PCR method was used to study the presence of $\beta$-galactosidase genes. A total of six primer pairs were designed to replicate $\beta$-galactosidase genes. The characteristics of designed primers such as GC percentage, temperature $\mathrm{Tm}$, and the probability of loop formation were individually examined by using of soft-Analyzer Oligo (Developer: Molecular Biology Insights Inc. version: 7, USA). PCR was performed as described by the manufacturer (PEQLAB ${ }^{\circledR}$ Thermocycler) and the amplified genes were evaluated for the expected products on $1.5 \%$ agarose gel and photographed on a UV Trans illuminator Ingenious LBR model [11]. The specific primers designed are shown in Table 2.

Pyruvate and acetate assays. The colorimetric method was used for the determination of pyruvate and acetate content in xanthan product. The percentage of pyruvate and acetate was measured by 2 and 4 di-nitrophenylhydrazine and hydroxamic acid methods, respectively $[16,19]$. The standard acetylcholine and pyruvate curves were prepared and the commercial xanthan powder (Sigma-Aldrich) was used as control.

Fourier Transform Infrared Spectroscopy (FTIR) Analysis. Fourier transform infrared spectrum (FTIR) was used to identify the functional groups in the structure of xanthan gum [20, 21]. The infrared spectra of xanthan from the current study and commercial xanthan (from Xanthomonas campestris; Sigma-Aldrich; No: 11138-62-2) were compared. The product of xanthan was powdered and mixed with $\mathrm{KBr}$ and was prepared as a pellet. Samples were analyzed using Perkin Elmer Fourier Transform Infrared, with wavelength ranging from 400 to 4000 waves/cm with 32 scans/samples [Perkin Elmer, spectrum one] [9, 19].

Statistical Analysis. All experiments were replicated in thrice and the data were analyzed by using the SPSS ${ }^{\circledR} 12$ software. A value of $P<0.05$ was considered as statistical significance.

\section{Results and Discussion}

Cell Growth during Fermentation. To investigate the growth rate of bacteria in the production medium, optical absorption at $600 \mathrm{~nm}$ and colony count were recorded at the time of sampling. As shown in Fig. 1, $A$, almost all strains reached a logarithmic phase $\left(\mathrm{OD}_{600}\right.$ of $\left.\leq 2\right)$ between $16-24 \mathrm{~h}$. Based 
Ta ble 2. Primers used in this study

\begin{tabular}{|c|c|c|}
\hline Primers & Sequence & Product size, bp \\
\hline$X c i / \beta$-gall F & 5' AGATCGAGAACGAATACAGC 3' & \multirow{2}{*}{343} \\
\hline$X c i / \beta$-gall R & $5^{\prime}$ TACAGGTTGAACGAATAGCC $3^{\prime}$ & \\
\hline$X c i / \beta$-gal2 F & 5' AATCCCAGTGACCACTACGC 3' & \multirow{2}{*}{465} \\
\hline$X c i / \beta$-gal2 R & 5' GCTGTTTTCGACCAGGACAT 3' & \\
\hline$X c i / \beta$-gal3 F & 5' TATGGCTCATCTTGCTGCTG 3' & \multirow{2}{*}{543} \\
\hline$X c i / \beta$-gal3 R & 5' CGTTGTATCCGCTGTTGATG 3' & \\
\hline Xci/ß-gal4 F & 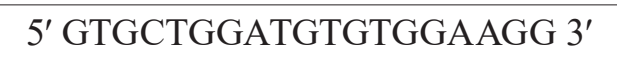 & \multirow{2}{*}{231} \\
\hline$X c i / \beta$-gal4 R & 5' ATAGCGGGTGTAGTCGATGC 3' & \\
\hline$X c i / \beta$-gal5 F & 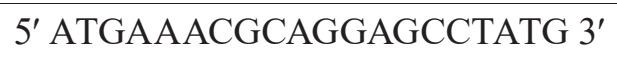 & \multirow{2}{*}{376} \\
\hline Xci/ß-gal5 R & 5' GATACACCCACATGCCTTCC 3' & \\
\hline$X c i / \beta$-gal6 F & 5' GTTTCGTGAGTGCATCGTGT 3' & \multirow[t]{2}{*}{164} \\
\hline$X c i / \beta$-gal6 R & 5' CTTCGTAGAACCAGCCTTCG 3' & \\
\hline
\end{tabular}

A

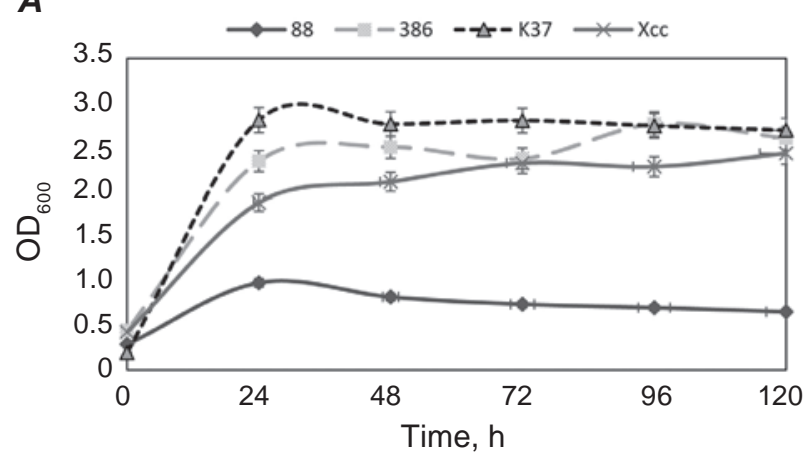

B

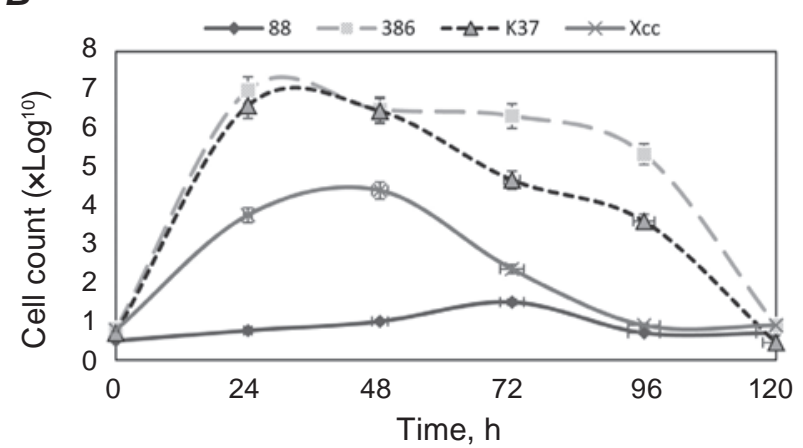

Fig. 1. Comparison of the growth rate of Xanthomonas strains in whey medium during fermentation: (A) cell count by optimal density at $600 \mathrm{~nm}$, and (B) cell count by colony counting on YM agar ( $P \leq 0.05)$

on the data, after around $24 \mathrm{~h}$, the bacterial growth was substantially constant except for the NIGEB-088 strain, which showed poor growth $\left(\mathrm{OD}_{600}=1\right)$ in the whey medium. The colony count also showed that the number of bacteria decreased sharply after $24 \mathrm{~h}$ of the beginning of the process, and then entered a stationary phase (Fig. 1, B).

Lactose Consumption and $\beta$-Galactosidase Activity. In NIGEB-386 and NIGEB-K37 strains, the amount of lactose sugar was significantly decreased after 24 h (Fig. 2, B). The NIGEB-088 strain did not use lactose sugar. The reduction of lactose in NIGEB-386 and NIGEB-K37 strains and even $X c c / D S M Z 1706$ was consistent with the increase of $\beta$-galactosidase enzyme activity. The highest enzyme activity was measured for NIGEB-
K37 and NIGEB-386 strains after $96 \mathrm{~h}$ with values of $1259.31 \mathrm{U} / \mathrm{ml}$ and $1302.98 \mathrm{U} / \mathrm{ml}$, respectively $(P \leq 0.05)$ (Fig. 2, A).

Xanthan Production and Viscosity. The results of the culture viscosity of the $X$. citri strains during fermentation are shown in Fig. 3, A. During the first $72 \mathrm{~h}$, there was no change in the viscosity of the culture media, but after $72 \mathrm{~h}$, the viscosity increased exponentially. The strain NIGEB-386 showed the highest viscosity score (2066.6 mPa.s); however, the strain NIGEB-088 did not change the medium viscosity and produce any xanthan. Xanthan gum produced by the other strains was dried and then weighed after precipitation by ethanol. After 48 to $72 \mathrm{~h}$ (in the early stationary phase), xanthan production began. At the end of the fermentation pro- 

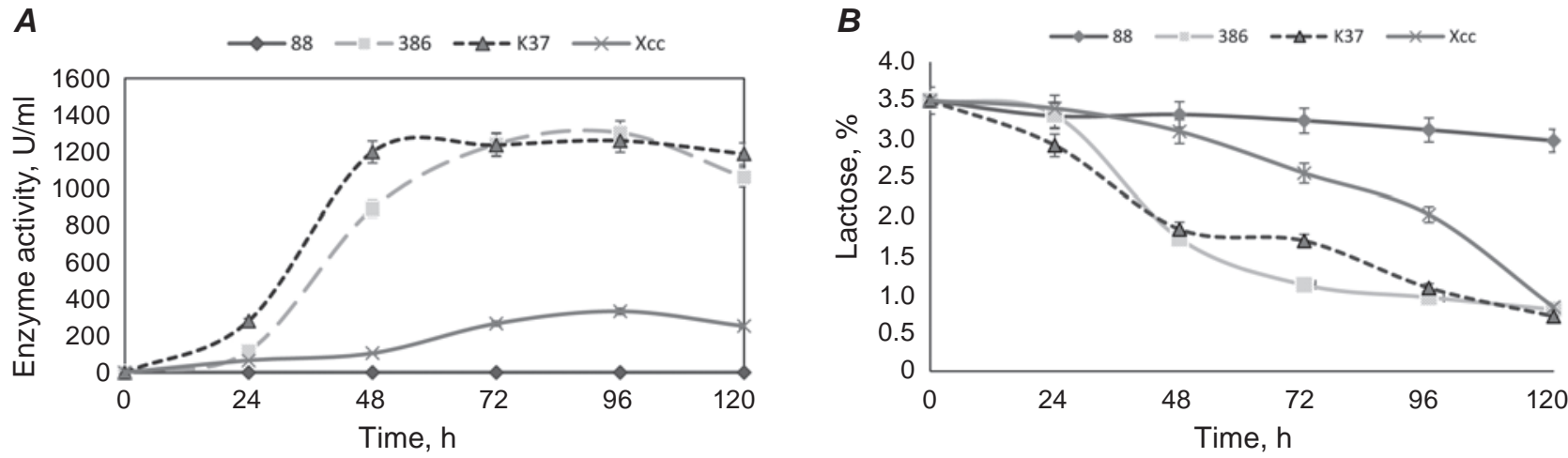

Fig. 2. Comparison of enzyme activity and lactose consumption by studied strains in cheese whey medium. (A) $\beta$-galactosidase activity, and (B) lactose consumption by strains $(P \leq 0.05)$

cess, the strains NIGEB-386, NIGEB-K37 and XcCl DSMZ1706 produced 20.3, 18.4 and $13.7 \mathrm{~g} / \mathrm{l}$ of xanthan, respectively $(P \leq 0.05)$ (Fig. $3, B)$.

$\beta$-Galactosidase genes of strains. To understand the relationship between $\beta$-galactosidase activity and the presence of related genes, PCR was performed in two strains of NIGEB-K37 and NIGEB-386, which had the highest $\beta$-galactosidase activity (Fig. 2). Bands with specific sizes ranging from 164 to $543 \mathrm{bp}$ are related to $\beta$ gal 1 to 6 genes (Fig. 4, 5). These results confirmed that all 6 genes are involved in elevating the $\beta$-galactosidase level in Xcc/DSMZ1706 as control and both NIGEB-K37 and NIGEB-386 strains. There were differences in the concentration of some amplified fragments, as well as in the occurrence of numerous non-specific bands (Fig. 5).

The chemical structure of xanthan. Comparison of the fermentation results showed that the strain NIGEB-386 was superior to the NIGEB-K37 regarding the concentration of the final product and viscosity of the culture broth, so it was selected for further studies and structural analysis. Comparison of xanthan viscosity of $1 \%(\mathrm{w} / \mathrm{v})$ solution, acetate and pyruvate content of the produced polymer by $X$. citri/NIGEB-386 and Xcc/DSMZ1706 with commercial xanthan gum (Sigma-Aldrich) is shown in Table 3. FTIR spectra of xanthan gum from strain Xci/386 was compared with that of standard xanthan gum (Sigma-Aldrich) for the characterization of functional groups (Fig. 6). The presence of carbonyl, hydroxyl and acetyl groups has been confirmed in xanthan's structure. The most important bands recorded in the range of $4000-400 \mathrm{~cm}^{-1}$ were as follow: 3420-3430 $\mathrm{cm}^{-1}$ : $-\mathrm{OH}$; 2850-2950 $\mathrm{cm}^{-1}$ : C-H and CHO; 1710-1735 cm-1: C=O ester, acid carboxylic, aldehydes and ketones; $1600-1630 \mathrm{~cm}^{-1}$ : $\mathrm{C}=\mathrm{O} 1400$ $1415 \mathrm{~cm}^{-1}$ : C-H and 1050-1255 $\mathrm{cm}^{-1}$ : C-O (Table 4).
A

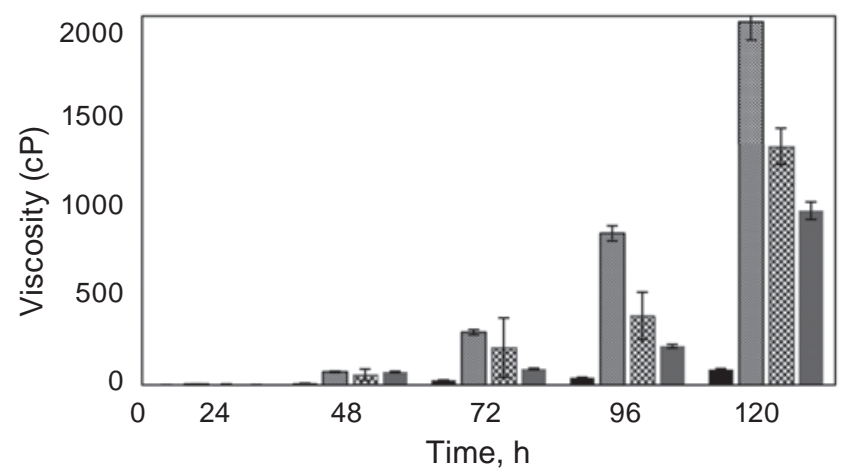

B

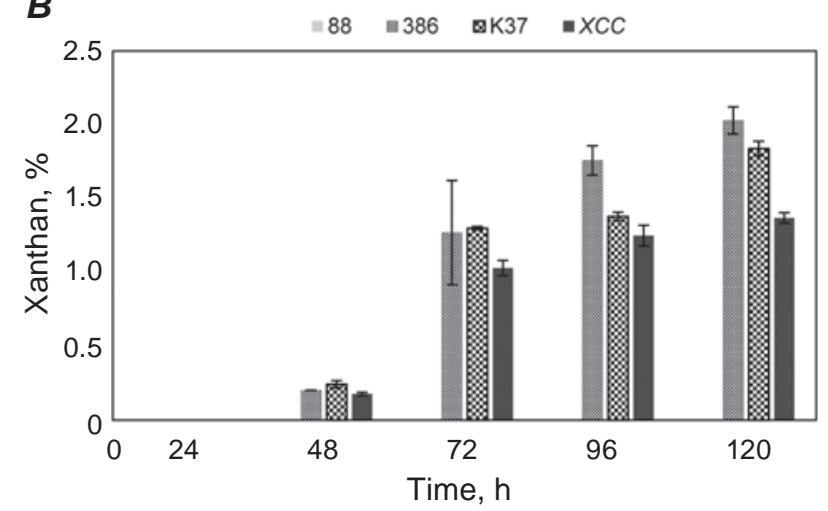

Fig. 3/ Comparison of Xanthan production behavior by studied strains in cheese whey medium (A) Viscosity of the fermentation broth which measured by Ostwald viscometer. (B) Dry weight of xanthan produced (g/l), $(P \leq 0.05)$ 


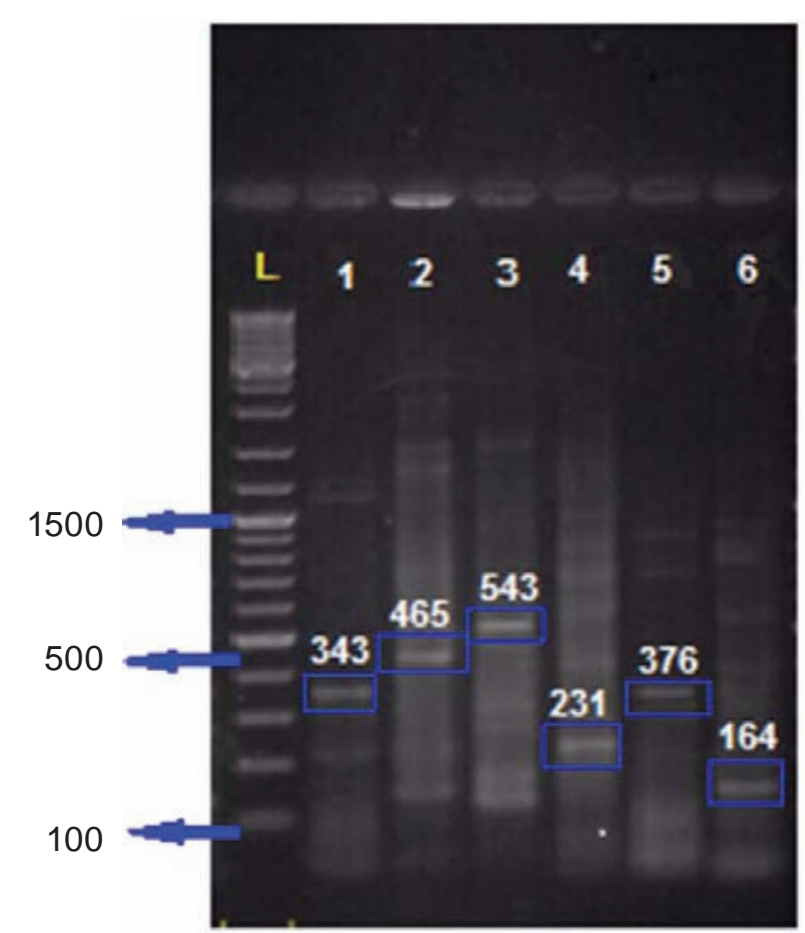

Fig. 4/ Gel electrophoresis of $\beta$-galactosidase genes in PCR products of X. campestris DSM1706(XcC/ DSM1706) as control. Lane L: DNA ladder $100 \mathrm{bp}$ plus, Lane 1-6: PCR fragments with specified size
In spite of minor differences of recorded picks in the FTIR spectra, the correspondence between bands led them to assert a strong similarity between commercial xanthan (Sigma-Aldrich) and produced xanthan by strain NIGEB-386 due to acid groups presents.

Generally, glucose, sucrose and starch are used as the most important sources for xanthan gum production. But the use of cheaper sources of carbon from agricultural and industrial wastes such as molasses and whey can be considered more appropriate for the production of xanthan at the industrial scale [20]. Due to the entry of industrial wastewater into the environment and surface water, the level of BOD would increase, which has gained environmental concerns [22]. One of the strategies for reducing BOD level is the use of whey as a suitable food source for the production of microbial products such as xanthan [16]. Whey is rich in lactose and the use of those Xanthomonas strains, which have a natural ability to utilize unconventional sugars such as lactose, will be more economical [15]. $X$. campestris is often used for the production of xanthan. This study evaluated the suitability of native and non-GMO strains of Xanthomonas citri for the production of xanthan in whey containing medium. In all the ex-
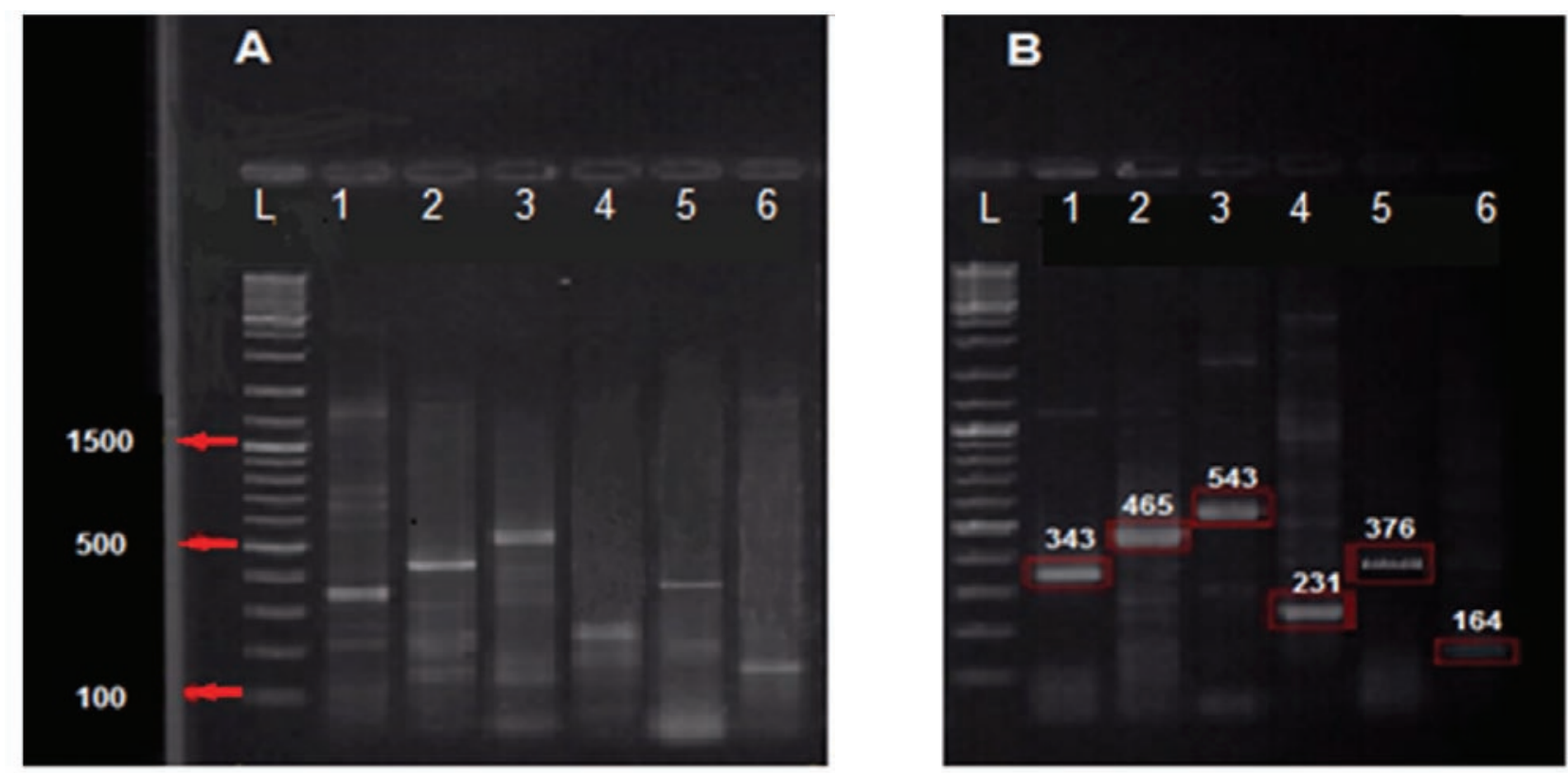

Fig. 5. Gel electrophoresis of $\beta$-galactosidase genes in PCR products of local isolated Xanthomonas citri strain A) $\beta$-galactosidase genes are discriminated by band length in Xci/ NIGEB-K37. Lane L: indicates DNA ladder 100bp plus. Lane 1-6: include the PCR products. B) Gel electrophoresis of Xci/NIGEB-386. Lane L: DNA ladder 100 bp plus, Lane 1-6: PCR fragments with specified size 
Ta b le 3. The comparison of viscosity and acetate - pyruvate contents in commercial and laboratory made xanthan samples

\begin{tabular}{lcccc}
\hline \multicolumn{1}{c|}{ Acetate $(\% \mathrm{w} / \mathrm{w})$} & Pyruvate $(\% \mathrm{w} / \mathrm{w})$ & Viscosity $(\mathrm{mPa} . \mathrm{s})^{\mathrm{a}}$ & Bacteria $^{\mathrm{a}}$ \\
\hline X. citri/NIGEB-386 & $325 \pm 5^{\mathrm{b}}$ & $2.1 \pm 0.1$ & $0.289 \pm 0.01$ \\
X.c/DSMZ1706 & $207 \pm 17$ & $1.73 \pm 0.05$ & $0.17 \pm 0.0$ \\
X. $_{\text {campestris }}$ & $695 \pm 12$ & $5.40 \pm 0.03$ & $0.33 \pm 0.0$ \\
\hline
\end{tabular}

${ }^{a}$ Xanthan $\left(1 \% \mathrm{w} / \mathrm{v}\right.$ solution). ${ }^{\mathrm{b}}$ Mean $\pm \mathrm{SD}(n=5) .{ }^{\mathrm{c}}$ Commercial xanthan (Sigma-Aldrich $\left.{ }^{\circledR}\right)$

Ta b le 4. Spectra of functional groups in standard xanthan and xanthan product of Xci/NIGEB-386

\begin{tabular}{l|c|c|c|c}
\hline \multicolumn{1}{c|}{ Functional groups } & Hydroxyl & Carbonyl & Carboxyl & Acetyl \\
\hline Standard xanthan gum (Sigma-Aldrich $\left.{ }^{\circledR}\right)$ & 3426 & $1634 ; 1733$ & $1253 ; 1454$ & $1076 ; 2927$ \\
Xanthan gum synthesized by Xci//NIGEB-386 & 3421 & $1611 ; 1735$ & $1252 ; 1454$ & $1076 ; 2933$ \\
\hline
\end{tabular}

periments, the $X c c / D S M 1706$ strain was used as a positive control. The $\beta$-galactosidase activities of NIGEB-386 and NIGEB-K37 strains were about 16fold more than that of $X c c / D S M 1706$ (1302 U/ml and $1259 \mathrm{U} / \mathrm{ml}$, respectively, vs. $333 \mathrm{U} / \mathrm{ml})(P \leq 0.05)$. The comparison of graphs A and B in Fig. 2 suggests that because of higher $\beta$-galactosidase activity, the bacteria were able to use lactose and eventually reduce the amount of lactose at the end of the process. On the other hand, strain 88 's inability to consume the lactose was consistent with the inactivation of $\beta$-galactosidase and the lack of ability for bacterial growth. This enzyme activity level was already enough to support growth and also confirm the ability of the NIGEB-K37 and NIGEB-386 strains to consume lactose in whey [10].

Various strains of Xanthomonas species can produce xanthan gum with different carbon sources; however, the highest amount of xanthan gum (about $14 \mathrm{~g} / \mathrm{l})$ was produced by the wild type of $X$. campestris from lactose source [5, 23]. Ramezani et al., [15] showed that the highest amount of produced xanthan by the NIGEB-K37 strain in a lactose-based medium (lactose $10 \%$ ) was $14.26 \mathrm{~g} / 1$. In this study, we increased the amount of the product to $18.4 \mathrm{~g} / \mathrm{l}$ in the cheese whey medium without the addition of more lactose by the NIGEB-K37. Cheese whey has a lot of nutritious sources and is cheaper than other lactose sources. Increased viscosity and xanthan production by the NIGEB-386 and NIGEB-K37 strains corresponded with their $\beta$-galactosidase activity. Obviously, in an environment, where only lactose is present, the bacteria should be able to use lactose to synthesize xanthan. The ability to use lactose requires the presence of $\beta$-galactosidase activity in bacteria [24]. Therefore, the absence of xanthan production in the NIGEB-088 strain could be attributed to the lack of $\beta$-galactosidase enzyme activity.

The activity and expression of the genes involved in the process of lactose utilization by the bacterial strains associated with citrus canker disease (X. citri subsp citri 306, X. fuscans subsp. aurantifulii and $X$. alfalfa subsp. citromelonis) have not been investigated extensively [25]. However, based on the $\beta$-galactosidase genes registered in the gene database (NCBI), as well as the use of the ONPG substrate and its relationship with the expression level of the lac operon, the presence of these genes in the native strains is possible [26]. Yang et al., [10] carried out a PCR amplification to detect the $\beta$-galactosidase gene in a strain of $X c 17$ (X. campestris 17). Their results indicated that $X c 17$ indeed contained a $\beta$-galactosidase gene; however, the enzyme levels were too low to support the growth of the on lactose-containing medium. The PCR results of this study confirmed the presence of $\beta$-galactosidase genes in the native strains of NIGEB-386 and NIGEB-K37. Although the sequencing of these genes was not carried out in this study, previous studies have shown that the position of these genes varies on the Xanthomonas citri genome and some of them are functional and some are also putative genes [27]. The relatively high activity of $\beta$-galactosidase in both strains (NIGEB386 and K37) compared with the commercial strain of Xcc/DSM1706 may indicate a remarkable expression level of these genes. Howe- 


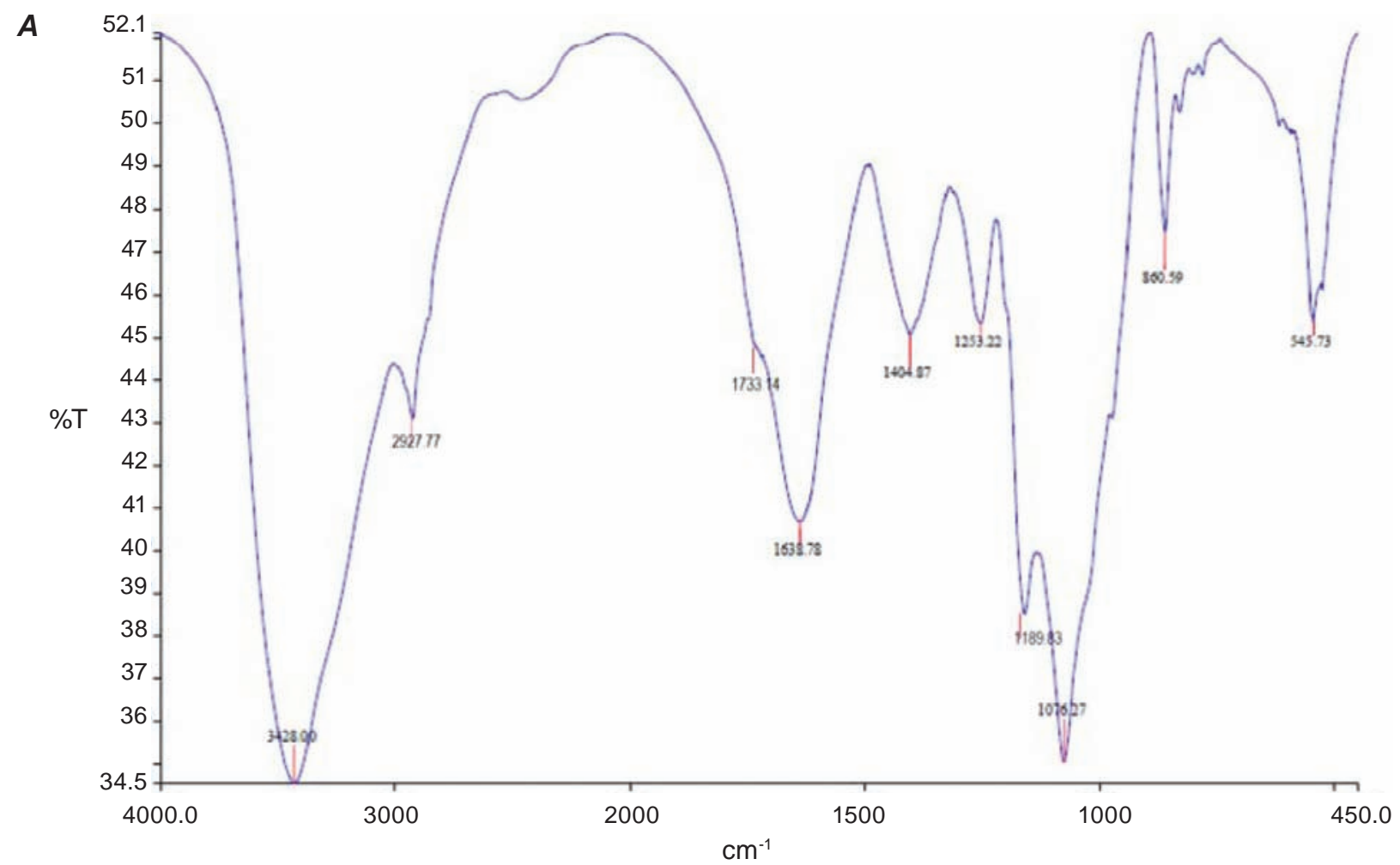

B

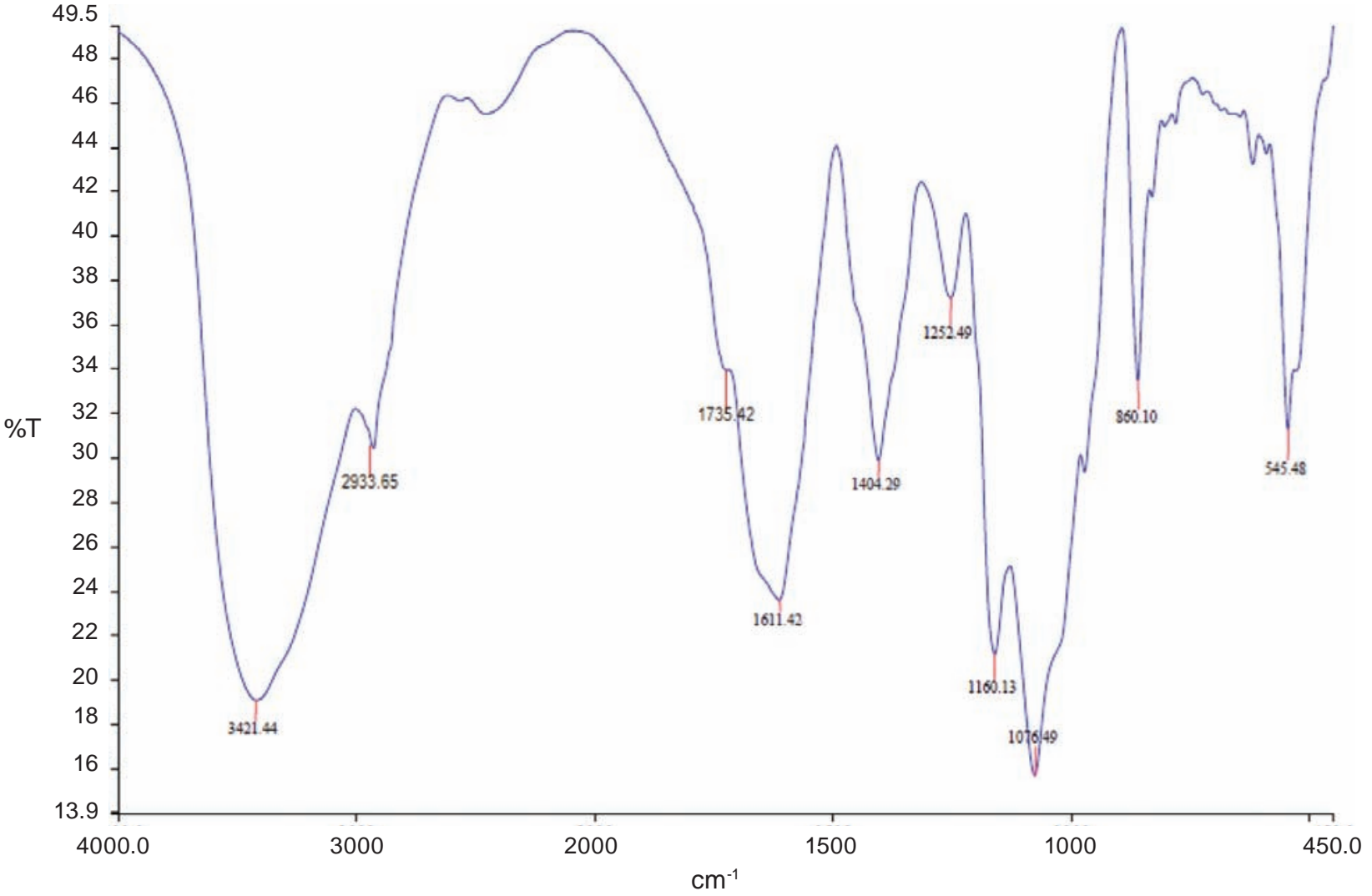

Fig. 6. FT-IR spectrum of xanthan samples (A) standard xanthan powder (Sigma-Aldrich ${ }^{\circledR}$ ), and (B) Xanthan product of Xci/NIGEB-386 
ver, to achieve the expression level of each of these genes, techniques such as Real-time PCR should be performed [23].

Remarkable apparent viscosity was observed in the culture broth of both strains at the end of fermentation. The purified xanthan viscosity of Xci/ NIGEB-386 was more than xanthan viscosity produced by $X c c / D S M 1706$; however, it was approximately equal to one second of the commercial xanthan (Sigma-Aldrich) (Table 3). Research has shown that increasing the acetate and pyruvate contents in the xanthan structure have very significant effects on increasing its viscosity [21]. However, our results showed that acetate content is relatively similar in both xanthan samples. Although the type of microorganism and the environmental conditions are two important factors affecting the structure of xanthan, the rheological properties of xanthan caused by acetate in increasing the viscosity are consistent with the results of Rodriguez et al., [25]. Other studies have also shown that high content of pyruvate and lower acetate increases the viscosity of the xanthan solution [28]. Therefore, with increasing pyruvate content (to $0.1-0.5 \%$ ), viscosity also increases by about 60 to $80 \%$.

The present study showed that there is a direct correlation between pyruvate content and viscosity, because pyruvate content and viscosity of $1 \%(\mathrm{w} / \mathrm{v})$ solution of standard xanthan is about 2.5 times higher than the pyruvate content and viscosity of xanthan obtained from strain NIGEB-386. The pyruvic acid content appears to be the best indicator of xanthan quality, and the percentage of acetylation and pyruvation of mannose in the xanthan structure can affect viscosity and rheological properties [4]. Although the environmental condition is an important factor in structural variation and rheological properties of xanthan [29], it does not affect the initial structure of xanthan but instead changes the formation of the xanthan's secondary structure, molecular weight, and production efficiency $[5,6]$.

FTIR is a method for detecting similarities and differences in the chemical structure of compounds $[9,22,30]$. In spite of minor differences of obtained peaks in the FTIR spectra, the results of this study showed that the infrared spectrum of xanthan produced by strain NIGEB-386 is very similar to that of the purified xanthan (Sigma-Aldrich ${ }^{\circledR}$ ). Silva et al., [28] evaluated two strain X. campestris 1866 and 1867 for xanthan production and showed that using different carbon sources and strains, the FTIR spec- tra in each of the two strains have similar functional groups.

These results confirmed that compared to the commercial strain $X$. campestris, the use of strain Xci/NIGEB-386 for producing xanthan in lactoseenriched medium such as cheese whey, could be promising. As further studies, the optimization of factors affecting growth and xanthan production, such as nitrogen, mineral resources, aeration rate and initial inoculation to improve the fermentation process, are continued.

Conflict of interest. Authors have completed the Unified Conflicts of Interest form at http://ukrbiochemjournal.org/wp-content/uploads/2018/12/ coi_disclosure.pdf and declare no conflict of interest.

Acknowledgment. The authors are thankful for support and cooperation of National Institute of Genetic Engineering and Biotechnology and Iranian Research Organization for Science and Technology.

\section{ФІЗИКО-ХІМІЧНІ \\ ХАРАКТЕРИСТИКИ І ОДЕРЖАННЯ КСАНТАНОВОЇ КАМЕДІ ЗА ДОПОМОГОЮ НАТИВНИХ ІЗОЛЯТІВ Xanthomonas citri subsp. citri, ЯКІ ПЕРЕТВОРЮЮТЬ ЛАКТОЗУ}

\author{
Roya Moravej ${ }^{1}$, Seyed Mehdi Alavi ${ }^{\bowtie}$, \\ Mehrdad Azin ${ }^{3}$, Ali Hatef Salmanian ${ }^{2}$ \\ ${ }^{1}$ Department of Biology, Science and Research \\ Branch, Islamic Azad University, Tehran, Iran; \\ ${ }^{2}$ Department of Plant Biotechnology, \\ National Institute of Genetic Engineering and \\ Biotechnology (NIGEB), Tehran, Iran; \\ ${ }^{3}$ Department of Biotechnology, Iranian \\ Research Organization for Science \\ and Technology (IROST), Tehran, Iran; \\ ${ }^{\mathrm{e}-m a i l: m e a l a v i @ n i g e b . a c . i r ~}$
}

Ксантан - це біополімер, що виробляється бактеріями Xanthomonas і який широко використовується в багатьох галузях промисловості (в харчовій та маслоробній). У роботі вивчали три штами Xanthomonas (X. citri/NIGEB-88, $X$. citri/NIGEB-386 i $X$. citri/NIGEB-K37) на предмет оцінки їх промислового потенціалу за отримання ксантанової камеді в молочно-сироватковому середовищі. В процесі ферментації вимірювали швидкість росту бактерій, в'язкість, кількість біомаси, суху масу одержаного ксан- 
тану і активність $\beta$-галактозидази. Присутність генів $\beta$-галактозидази оцінювали методом ПЛР. Штам NIGEB-386 виявив найкращу здатність перетворювати лактозу в молочно-сироватковому середовищі. Найбільші значення кількості і в'язкості ксантану становили 22,7 г/л і 2066,6 мПа·с відповідно. Було підтверджено наявність шести генів $\beta$-галактозидази в штамax NIGEB-386 і NIGEB-K37. Вміст пірувату i ацетату в ксантановій камеді становив 2,1 i 0,29\% відповідно. За допомогою інфрачервоної Фур'є-спектроскопії було визначено положення функціональних груп у структурі продукту ферментації. У молочно-сироватковому середовищі показники двох штамів NIGEB-386 i NIGEB-K37 були кращими порівняно $3 X$. campestris. Показано, що Xanthomonas citri/NIGEB-386 придатний для промислового виробництва ксантану з використанням молочної сироватки як недорогого середовища.

Ключов і слов а: Xanthomonas citri, ксантанова камедь, молочна сироватка, $\beta$-галактозидаза, вміст пірувату і ацетату, інфрачервона Фур'є-спектроскопія.

\section{References}

1. Guo Y, Sagaram US, Kim J-s, Wang N. Requirement of the galU gene for polysaccharide production by and pathogenicity and growth In Planta of Xanthomonas citri subsp. citri. Appl Environ Microbiol. 2010; 76(7): 2234-2242.

2. Pegos VR, Canevarolo RR, Sampaio AP, Balan A, Zeri ACM. Xanthan Gum Removal for 1H-NMR Analysis of the Intracellular Metabolome of the Bacteria Xanthomonas Axonopodis Pv. Citri 306. Metabolites. 2014; 4(2): 218-231.

3. Garcia-Ochoa F, Santos VE, Casas JA, Gómez E. Xanthan gum: production, recovery, and properties. Biotechnol Adv. 2000; 18(7): 549-579.

4. Mirik M, Demirci AS, Gumus T, Arici M. Xanthan gum production under different operational conditions by Xanthomonas axonopodis pv vesicatoria isolated from pepper plant. Food Sci Biotechnol. 2011; 20(5): 12431247.

5. Lopes BM, Lessa VL, Silva BM, Carvalho Filho MAS, Schnitzler E, Lacerda LG. Xanthan gum: properties, production conditions, quality and economic perspective. J Food Nutr Res. 2015; 54(3): 185-194.
6. Kool MM, Gruppen H, Sworn G, Schols HA. Comparison of xanthans by the relative abundance of its six constituent repeating units. Carbohydr Polym. 2013; 98(1): 914-921.

7. Palaniraj A, Jayaraman V. Production, recovery and applications of xanthan gum by Xanthomonas campestris. J Food Eng. 2011; 106(1): 1-12.

8. Gunasekar V, Reshma KR, Treesa G, Gowdhaman D, Ponnusami V. Xanthan from sulphuric acid treated tapioca pulp: influence of acid concentration on xanthan fermentation. Carbohydr Polym. 2014; 102: 669-673.

9. Niknezhad SV, Asadollahi MA, Zamani A, Biria D, Doostmohammadi M. Optimization of xanthan gum production using cheese whey and response surface methodology. Food Sci Biotechnol. 2015; 24(2): 453-460.

10. Yang TC, Hu RM, Weng SF, Tseng YH. Identification of a hypothetical protein of plant pathogenic Xanthomonas campestris as a Novel $\beta$-galactosidase. J Mol Microbiol Biotechnol. 2007; 13(1-3): 172-180.

11. Yang TC, Hu RM, Hsiao YM, Weng SF, Tseng YH. Molecular genetic analyses of potential $\beta$-galactosidase genes in Xanthomonas campestris. J Mol Microbiol Biotechnol. 2003; 6(3-4): 145-154.

12. Ashraf S, Soudi MR, Sadeghizadeh M. Isolation of a novel mutated strain of Xanthomonas campestris for xanthan production using whey as the sole substrate. Pak J Biol Sci. 2008; 11(3): 438-442.

13. Kamal F, Mehrgan H, Assadi MM, Mortazavi SA. Mutagenesis of Xanthomonas campestris and selection of strains with enhanced xanthan production. Iran Biomed J. 2003; 7(3): 91-98.

14. Schwartz RD, Bodie AE. Production of highviscosity whey broths by a lactose-utilizing Xanthomonas campestris strain. App Environ Microbiol. 1985; 50(6): 1483-1485.

15. Ramezani A, Jafari M, Goodarzi T, Alavi SM, Salmanian AH, Azin M. Lactose consuming strains of Xanthomonas citri subsp. citri (Xcc) insight into the emergence of natural field resources for xanthan gum production. World $J$ Microbiol Biotechnol. 2014; 30(5): 1511-1517.

16. Mesomo M, Silva MF, Gabriela Boni, Padilha FF, Mazutti M, Mossi A, de Oliveira D, Cansian RL, Luccio M, Treichel H. Xanthan gum produced by Xanthomonas campestris from cheese whey: production optimisation and rheological 
characterisation. J Sci Food Agric. 2009; 89(14): 2440-2445.

17. Vujicic IF, Lin AY, Nickerson TA. Changes during acid hydrolysis of Lactose. J Dairy Sci. 1977; 60(1): 29-33.

18. Miller GL. Use of dinitrosalicylic acid reagent for determination of reducing sugar. Anal Chem. 1959; 31(3): 426-428.

19. Soleymanpour Z, Nikzad M, Talebnia F, Niknezhad V. Xanthan gum production from acid hydrolyzed broomcorn stem as a sole carbon source by Xanthomonas campestris. 3 Biotech. 2018; 8(7): 296.

20. Moosavi A, Karbassi A. Bioconversion of sugarbeet molasses into xanthan gum. J Food Process Preserv. 2010; 34(2): 316-322.

21. Erten T, Adams GG, Foster TJ, Harding SE. Comparative heterogeneity, molecular weights and viscosities of xanthan of different pyruvate and acetate content. Food Hydrocol. 2014; 42: 335-341.

22. Faria S, de Oliveira Petkowicz CL, de Morais SAL, Terrones MGH, de Resende MM, de França FP, Cardoso VL. Characterization of xanthan gum produced from sugar cane broth. Carbohydr Polym. 2011; 86(2): 469-476.

23. Gumus T, Demirci AS, Mirik M, Arici M, Aysan Y. Xanthan gum production of Xanthomonas spp. Isolated from different plants. Food Sci Biotechnol. 2010; 19(1): 201-206.

24. Silva MF, Fornari RCG, Mazutti MA, de Oliveira D, Padilha FF, Cichoski AJ, Cansian RL, Di Luccio $\mathrm{M}$, Treichel $\mathrm{H}$.
Production and characterization of xantham gum by Xanthomonas campestris using cheese whey as sole carbon source. J Food Eng. 2009; 90(1): 119-123.

25. Rodriguez-R LM, Grajales A, Arrieta-Ortiz ML, Salazar C, Restrepo S, Bernal A. Genomesbased phylogeny of the genus Xanthomonas. BMC Microbiol. 2012; 12: 43.

26. Fu JF, Tseng YH. Construction of lactoseutilizing Xanthomonas campestris and production of xanthan gum from whey. Appl Environ Microbiol. 1990; 56(4): 919-923.

27. Jalali A, Alavi SM, Sangtarash MH. Comparative genomic analysis of wide and narrow host range strains of Xanthomonas citri subsp. citri, showing differences in the genetic content of their pathogenicity and virulence factors. Australas Plant Pathol. 2017; 46(1): 49-61.

28. da Silva JA, Cardoso LG, de Jesus Assis D, Gomes GVP, Oliveira MBPP, de Souza CO, Druzian JI. Xanthan Gum Production by Xanthomonas campestris pv. campestris IBSBF 1866 and 1867 from Lignocellulosic Agroindustrial Wastes. Appl Biochem Biotechnol. 2018; 186(3): 750-763.

29. Rehm BHA. Microbial production of biopolymers and polymer precursors: applications and perspectives, First ed., Caister Academic, Press, New Zealand 2009.

30. Zakeri A, Pazuki M, Vossugi M. Development of kinetic model for xanthan production in a laboratory-scale batch fermentor. Iran $J$ Sci Technol Trans A Sci. 2018; 42(1): 261-266. 